oldest bird was less than six and onehalf years of age when caught in a trap.

Recovery percentages varied widely. R. H. Carter, Jr. had only one recovery from 24 birds banded (under 3\%) and this writer had only two from 82 banded up until the end of 1966 (just over 2\%). On the other hand, the Wotherspoon brothers at Hyas had a phenomenal eight recoveries from 18 banded $(44 \%)$, with half of them from Texas.

Banded by R. H. Carter, Jr., Muscow, Sask. (504-1035) (24 banded) : June 23/29. Shot Dec. 6/29 (direct) Kennedy, Texas (284-0975).

Banded by J. R. Carter, Muscow, Sask. (504-1035) (3 banded) :

June 23/29. Captured Sept. 6/29 (direct) Rolla, Kansas (370-1013). Aug. 8/29. Flew into wire Sept. 11/29 (direct) Ft. Qu'Appelle, Sask. (504-1035).

Banded by Fred G. Bard (504 to $512-1021$ to 1052):

June 28/32. Shot Oct. 13/32 (direct) in Oklahoma (345-0982). June 29/34. Shot Aug. 26/34 (direct) in Washington (475-1222).

July 3/38. Caught in trap before Dec. 6/44 (6 yr.) in Texas (334-0982).

Banded by Bill and Lindsay Wotherspoon, Hyas, Sask. (516-1021) (18 banded): July 9/33. Shot Dec. 26/33 (direct) Archie, Misisouri (383-0942).

July 9/33. Shot Nov. 11/33 (direct) Wynnewood, Okla. (348-0968).

July 29/33. Shot Dec. 20/34 (1 yr.) Beaumont, Texas (300-0940).

July 29/33. Shot Nov. 24/33 (direct) New Orleans, La. (295-0900).

July 29/33. Shot Oct. 21/35 (2 yr.) Edna, Texas (285-0963).

July 1/34. Shot Nov. 15/34 (direct) Temple, Texas (310-0970).

April 25/36. Shot Feb. 6/37 (-1 yr.) Davie, Florida (260-0801).

July 16/44. Shot Oct. 1/44 (direct) in Texas (293-0975).

Banded by F. J. Hartley Fredeen, Macrorie, Sask. (511-1070):

July 8/41. Shot Dec./41 (direct) in Oklahoma (344-0995).

July 8/41. Found dead before Jan. 6/44 (-3 yr.) Nebraska (412-1022).

Banded by Dick Bird, Regina Beach, Sask. (504-1045):

July 10/45. Shot Feb. 10/46 (-1 yr.) in Neuvo Leon, Mexico.

Banded by C. Stuart Houston, Yorkton, Sask. (510-1020 and 512-1015):

June 30/59. Shot before Nov. 13/59 (direct) Monroe, La. (323-0920).

July 17/60. Shot Sept. 21/60 (direct) Martin, Georgia (342-0831).

Banded by Glen A. Fox, Battleford, Sask. (524-1081):

July $9 / 60$. Injured Sept. $1 / 60$ (direct) in New Mexico (342-1033).

July 1/61. Found dead Jan. 22/62 (-1 yr.) in Oklahoma (365-0944).

Banded by Wm. Anaka, Spirit Lake, Sask. (513-1023):

July 18/61. Shot. Nov. 30/61 (direct) in Georgia (312-0845).

July 18/61. Shot Nov. 22/62 (1 yr.) in Georgia (325-0843).

Banded by Walter and Billy Matthews, Nipawin, Sask. (532-1040):

June 30/51. Shot Sept. 15/51 (direct) Somme, Sask. (523-1025).

Note: $513-1023$ mean's $51^{\circ} 30^{\prime}$ North and $102^{\circ} 30^{\prime}$ West.

\title{
MIGRANT STARLING
}

by Sig Jordheim, White Bear

On June 16, $1967 \mathrm{my}$ children found a starling caught by one toe in a nest hole at a shed. They noticed a band on its leg, but being unable to get at the captive toe, they notified me and I helped them free the bird and get its number. This I sent to the U.S. Fish and Wildlife Service, and the Service has just notified me that the bird was banded at Los Banos, California on January 12,1962 . 